\title{
PENGARUH PENGGUNAAN LAHAN KAKAO YANG DIINTEGRASIKAN DENGAN KELAPA SAWIT TERHADAP KEANEKARAGAMAN SERANGGA PREDATOR DAN PARASITOID
}

\section{Effect of Cocoa Land Use that is be Integrated with Oil Palm on Diversity of Predator and Parasitoid Insects}

\author{
Nurfina Yenti ${ }^{1}$, Juniarti ${ }^{2}$, Siska Efendi ${ }^{3 *}$ \\ 1) Alumni Program Studi Agroekoteknologi, Fakultas Pertanian, Kampus III Universitas Andalas Dharmasraya. \\ 2) Program Studi Ilmu Tanah, Fakultas Pertanian, Universitas Andalas, Limau Manis, Padang (25163), Indonesia \\ ${ }^{3)}$ Program Studi Agroekoteknologi, Fakultas Pertanian, Kampus III Universitas Andalas Dharmasraya. \\ *email koresponden: siskaefendi@agr.unand.ac.id
}

Received: 2019. Revised: $19^{\text {th }}$ September 2019. Accepted: $20^{\text {th }}$ April 2020

\begin{abstract}
Abstrak
Perubahan tipe penggunaan lahan kakao monokultur menjadi polikultur secara tidak langsung akan mempengaruhi komponen penyusun ekosistem tersebut. Serangga adalah komponen biotik yang respon terhadap perubahan ekosistem, sehingga menarik untuk dikaji khususnya serangga predator dan parasitoid. Penelitian ini bertujuan untuk mengetahui pengaruh penggunaan lahan kakao yang diintegrasikan dengan kelapa sawit terhadap keanekaragaman serangga predator dan prasitoid. Penelitian ini dilaksanakan pada beberapa tipe penggunaan lahan yakni lahan kakao-kelapa sawit, kakao, kelapa sawit dan hutan di Nagari Sitiung, Kecamatan Sitiung, Kabupaten Dharmasraya. Penelitian ini berbentuk survei dengan metode penentuan petak sampel yakni systematic sampling menggunakan pola yang disesuaikan dengan bentuk masing-masing lahan. Metode pengambilan sampel yakni pitfall trap, yellow pan trap, insect net, dan hand collecting. Total serangga predator dan parasitoid yang dikoleksi terdiri dari 9 ordo, 33 famili, 84 morfospesies dan 2,848 individu. Keanekaragaman serangga predator dan parasitoid dipengaruhi oleh tipe penggunaan lahan $(p=0.0034)$. Keanekaragaman serangga pradator Serangga predator yang memiliki kelimpahan individu tertinggi pada semua lahan yakni Formicidae. Serangga parasitoid yang memiliki kelimpahan individu tertinggi yakni Braconidae pada lahan kakaokelapa sawit, Tachinidae pada lahan kakao, Tiiphidae pada lahan kelapa sawit dan Ichneumonidae pada hutan.
\end{abstract}

Kata kunci: Braconidae, formicidae, ichneumonidae, tachinidae, tiiphidae.

\begin{abstract}
Changes in land use cocoa monoculture into polycultures will affect the components of the ecosystems indirectly. Insects are biotic components that will response to ecosystem changes, so it is interesting to learn especially predator and parasitoid insects. The purpose of this research was to determine the influence of land use cocoa that was integrated with the palm oil on diversity of predator and parasitoid insects. This research was conducted on some types of land use, there are cocoa-palm oil land, cocoa land, palm oil land and forest in Nagari Sitiung, Kecamatan Sitiung, Kabupaten Dharmasraya. The method use for determining the sample plots by using a pattern adapted to the shape of each land. Predator and parasitoid insects were collected by pitfall trap, yellow pan trap, insect net, and hand collecting. Total predator and parasitoid insects that have been collected consists of 9 orders, 33 families, 84 morphospecies and 2,848 individuals. Diversity of predator and parasitoid insects is affected by land use $(p=0,0034)$. Predator insect that have the highest individual abundance in all lands is Formicidae. Parasitoid insects that have the highest individual abudance are Braconidae in cocoa-palm oil land, Tachinidae in cocoa land, Tiiphidae in palm oil land and Ichneumonidae in forest.
\end{abstract}

Keywords: Braconidae, formicidae, ichneumonidae, tachinidae, tiiphidae 


\section{PENDAHULUAN}

Dharmasraya merupakan salah satu kabupaten yang berada di Provinsi Sumatera Barat yang gencar mengembangkan sektor pertanian. Luas wilayah Kabupaten Dharmasraya yakni seluas 302,598 Ha. Pada tahun 2016 hampir setengah dari luas wilayah Kab. Dharmasraya $(123,995.11 \mathrm{Ha})$ digunakan untuk sektor pertanian dan 115,787 Ha diantaranya digunakan untuk komoditi perkebunan (BPS, 2017; Dinas Pertanian, 2017). Komoditi perkebunan andalan di Dharmasraya ialah kelapa sawit dan karet. Komoditi lain yang saat ini akan dikembangkan di Kab. Dharmasraya ialah kakao.

Pada tahun 2015 luas perkebunan kakao di Kab. Dharmasraya mencapai 1,984.81 Ha dan mengalami peningkatan hingga tahun 2016 menjadi 2,108.88 Ha (BPS, 2017). Untuk mengotimalkan ketersedian lahan di beberapa kecamatan di Kab. Dharmasraya budidaya kakao diintegrasikan dengan tanaman lain salah satunya kelapa sawit dengan pola tanam polikultur. Perubahan tipe penggunaan lahan dari kakao monokultur menjadi polikultur akan membentuk sebuah ekosistem yang berbeda dari segi kompleksitas komponen penyusun. Perbedaan penggunaan lahan tersebut secara tidak langsung akan mempengaruhi komponen penyusun ekosistem tersebut. Serangga adalah komponen biotik yang respon terhadap perubahan ekosistem, khususnya serangga predator dan parasitoid.

Serangga predator dan parasitoid memiliki fungsi esensial dalam menekan populasi serangga hama. Keberadaan serangga predator dan parasitoid pada suatu ekosistem dipengaruhi oleh faktor lingkungan. Faktor lingkungan yang mendukung keberadaan serangga predator dan parasitoid yakni ketersediaan tempat tinggal, pakan/makanan dan inang. Ekosistem dengan kondisi lingkungan yang kompleks dan heterogen akan menyediakan tempat tinggal, pakan/makanan dan inang yang banyak bagi serangga predator dan parasitoid. Keanekaragaman serangga predator dan parasitoid pada perkebunan kakao yang diintegrasikan dengan kelapa sawit akan lebih tinggi dibandingkan pada perkebunan kakao monokultur. Hal ini dikarenakan kondisi perkebunan kakao yang diintegrasikan dengan kelapa sawit lebih kompleks dan heterogen. (Krebs, 1978) menyatakan bahwa semakin heterogen suatu lingkungan fisik, semakin kompleks komunitas flora dan fauna di suatu tempat tersebut, maka semakin tinggi keanerakaraman jenisnya.

Informasi keanekaragaman serangga predator dan parasitoid pada penggunaan lahan polikultur antar komoditi perkebunan masih terbatas. Penggunaan lahan polikultur antar komoditi perkebunan yakni kakao yang diintegrasikan dengan kelapa sawit ditemukan di Nagari Sitiung, Kec. Sitiung, Kab. Dharmasraya. Penelitian ini bertujuan untuk mengetahui pengaruh pengunaan lahan kakao yang diintegrasikan dengan kelapa sawit terhadap keanekaragaman serangga predator dan parasitoid.

\section{METODE PENELITIAN}

\section{Penentuan Lokasi Penelitian}

Lokasi penelitian ditentukan menggunakan metode Purposive Random Sampling dengan beberapa kriteria yakni (1) lahan yang digunakan yakni lahan kakao-kelapa sawit, lahan kakao, lahan kelapa sawit, dan hutan (2) setiap lahan memiliki luas sekitar 0.5-1 Ha, (3) umur tanaman kakao dan kelapa sawit pada lahan polikultur dan monokultur adalah sama, dengan umur kelapa sawit yaitu 3-5 tahun dan umur kakao 8-10 tahun. Masing-masingnya tipe penggunaan lahan terdiri dari 2 lahan, sehingga total keseluruhan lahan yakni 8 lahan.

\section{Penentuan Petak Sampel}

Metode yang digunakan untuk menentukan petak sampel disesuaikan dengan bentuk masing-masing lahan, misalnya metode Systematic sampling, dengan pola diagonal yang digunakan pada lahan kakao yang diintegrasikan dengan kelapa sawit. Pada garis diagonal diletakan 5 petak sampel dengan ukuran 16 $\mathrm{m}^{2}(4 \mathrm{~m} \times 4 \mathrm{~m})$ sehingga diharapkan dalam 1 plot 
sampel ada 1 tanaman kelapa sawit dan 4 tanaman kakao sebagai tanaman sampel.

\section{Pengambilan sampel serangga}

Metode pengambilan sampel yakni pitfall trap, yellow pan trap, insect net dan hand collecting. Pitfall trap dan yellow pan trap diisi dengan air sabun sebanyak $1 / 3$ volume gelas plastic dan diinkubasi selama 24 jam. Penangkapan serangga menggunakan insect net dilakukan dengan cara mengayunkannya pada kanopi tanaman dalam petak sampel sebanyak 20 ayunan ganda. Pengambilan sampel serangga predator dan parasitoid pada masing-masing lahan dilaksanakan sebanyak 2 kali dengan interval waktu 1 bulan. Hand collecting dilakukan untuk mengoleksi serangga yang hinggap dan berada di sekitar tanaman dalam petak sampel.

\section{Identifikasi Serangga}

Serangga predator dan parasitoid yang didapat akan diidentifikasi sampai tingkat famili. Identifikasi serangga predator dan parasitoid untuk tingkat famili dilakukan dengan mengacu pada buku Pengenalan Pelajaran Serangga Edisi ke-enam oleh (Borror, Triplehorn, \& Johnson, 1996) buku Hymenoptera of the World: An Identification Guide to Families oleh (Goulet \& Huber, 1993) dan buku Kunci Determinasi Serangga (1991).

\section{Analisis Data}

Data yang telah diperoleh digunakan untuk menganalisis indek keanekaragaman ShannonWeiner ( $\left.\mathrm{H}^{\prime}\right)$ dan indeks kemerataan Simpson menggunakan aplikasi Primer 5. Nilai indeks keanekaragaman Shannon-Wiener, indeks kemerataan Simpson, kekayaan spesies dan kelimpahan spesies antar lahan penelitian yang didapat dianalisis menggunakan analisis sidik ragam (Analysis of Variance). Jika hasil analisis ragam menunjukkan pengaruh nyata maka dilanjutkan dengan uji lanjut Tukey HSD (Honestly Significance Diffirence) pada taraf kepercayaan 95\% menggunakan aplikasi Statistix 10 for Windows.

\section{HASIL DAN PEMBAHASAN}

\section{Komposisi Serangga Predator dan Parasitoid}

Total keseluruhan serangga yang terkoleksi di lapangan sebanyak 6,538 individu yang terdiri dari 15 ordo, 59 famili, dan 233 morfospesies. Serangga predator dan parasitoid yang terkoleksi terdiri dari 9 ordo, 33 famili, 84 morfospesies dan 2,848 individu. Pada lahan kakao-kelapa sawit ditemukan 9 ordo serangga predator dan parasitoid yang terdiri dari 29 famili, 50 morfospesies dan 878 individu. Pada lahan kakao ditemukan 8 ordo, 23 famili, 30 morfospesies dan 936 individu serangga predator dan parasitoid sedangkan pada lahan kelapa sawit yakni 8 ordo, 26 famili, 37 morfospesies dan 455 individu. Pada lahan hutan ditemukan 7 ordo serangga predator dan parasitoid yang terdiri dari 31 famili, 62 morfospesies dan 579 individu.

Pada Tabel 1 dapat dilihat bahwa lahan hutan memiliki jumlah famili dan morfospesies serangga predator dan parasitoid yang lebih banyak dibandingkan dengan lahan yang lain. Hal yang sama dilaporkan (Pelawi, 2009) dimana serangga pada lahan hutan di Kab. Labuhanbatu, Sumatera Utara lebih tinggi dibandingkan serangga pada lahan kelapa sawit menghasilkan, lahan kelapa sawit belum menghasilkan dan lahan bukaan baru. Hal ini disebabkan karena hutan merupakan ekosistem yang komplek dan memiliki tingkat heterogenitas yang tinggi. Kondisi yang heterogen ialah kondisi suatu ekosistem yang di dalamnya terdapat banyak variasi komponen penyusun ekosistem itu sendiri. Hutan ditumbuhi banyak vegetasi di antaranya banyak pepohonan besar, tumbuhan perdu, semak, dan belukar. Vegetasi yang beragam di dalam hutan akan menyediakan banyak tempat tinggal maupun makanan/pakan bagi serangga, sehingga banyak jenis serangga yang hidup di hutan. 
Tabel 1. Komposisi serangga predator dan parasitoid pada lahan kakao-kelapa sawit, kakao, kelapa sawit dan hutan

\begin{tabular}{lllll}
\hline Lahan & Jumlah & & & \\
\cline { 2 - 5 } & Ordo & Famili & Morfospesies & Individu \\
\hline Kakao-kelapa sawit & 9 & 22 & 38 & 825 \\
Predator & 2 & 7 & 12 & 53 \\
Parasitoid & 8 & 17 & 23 & 891 \\
Kakao & 2 & 6 & 7 & 45 \\
Predator & & & 28 & 416 \\
Parasitoid & 8 & 19 & 9 & 39 \\
Kelapa sawit & 2 & 7 & 42 & 465 \\
Predator & & 21 & 20 & 114 \\
Parasitoid & 7 & 10 & & \\
Hutan & 2 & & & \\
Predator & Parasitoid & &
\end{tabular}

Kelimpahan Serangga Predator dan Mantodea, Odonata, Orthoptera, dan Thysanoptera Parasitoid (Tabel 2). Ordo yang memiliki jumlah famili

Ordo serangga predator dan parasitoid yang ditemukan pada penelitian ini yakni Coleoptera, terbanyak yaitu ordo Hymenoptera, dengan jumlah 11 famili. Menurut (Goulet \& Huber, 1993). ordo Hymenoptera termasuk dalam 4 ordo terbesar selain

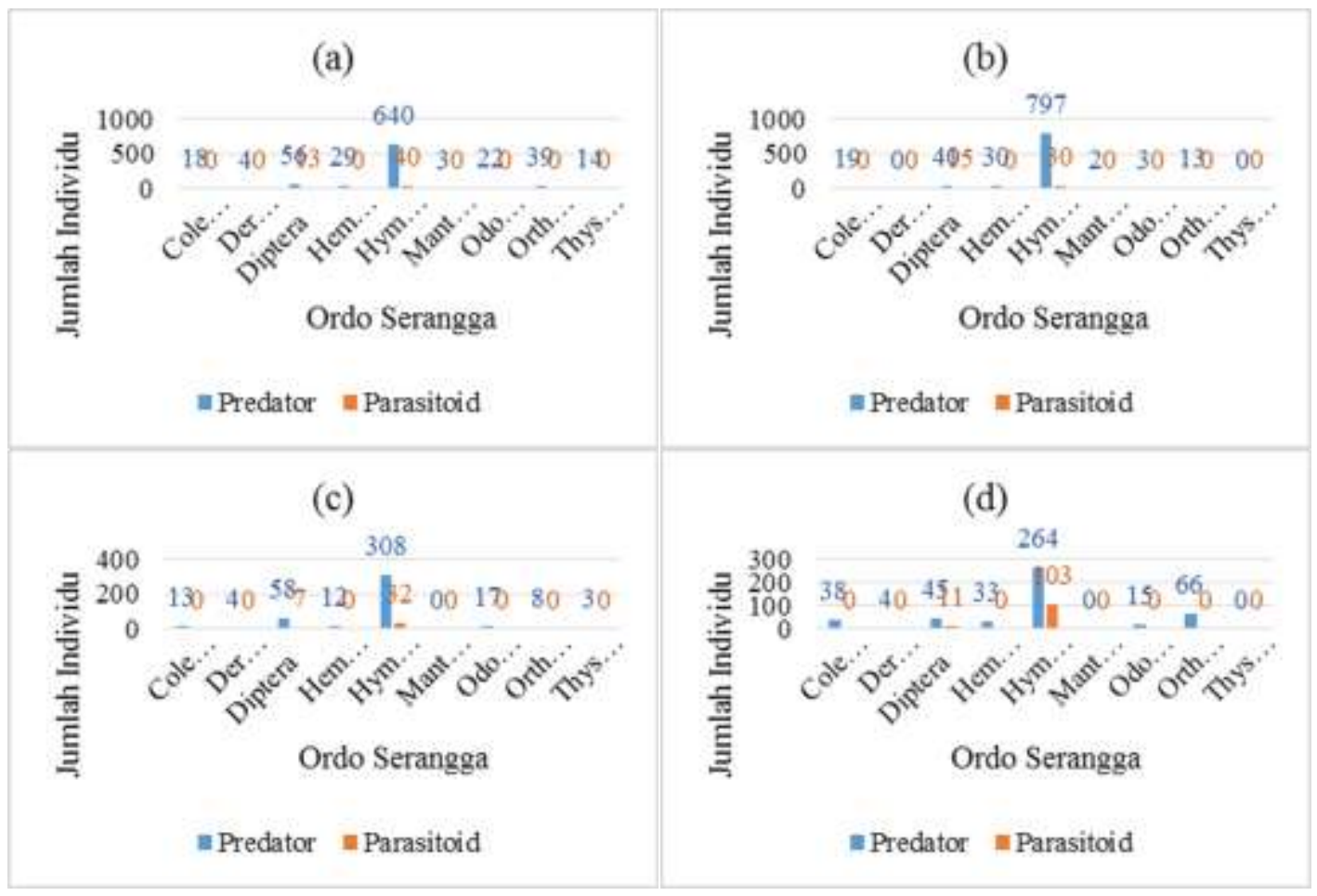

Gambar 1. Kelimpahan individu serangga predator dan parasitoid a) kakao-kelapa sawit, b) kakao, c) kelapa sawit dan d) hutan

Dermaptera, Diptera, Hemiptera, Hymenoptera, Coleoptera, Diptera dan Lepidoptera. Hal yang sama 
dilaporkan (Anbalagan, Paulraj, Ignacimuthu, Baskar, \& Gunasekaran, 2016) bahwa ordo Hymenoptera memiliki jumlah famili dan spesies tertinggi dibandingkan ordo lainnya.

Dari 2,848 individu serangga predator dan parasitoid yang terkoleksi, serangga predator lebih banyak ditemukan dibandingkan dengan serangga parasitoid. Jumlah individu serangga predator sebanyak 2,597 individu, sedangkan serangga parasitoid sebanyak 251 individu. Hal ini disebabkan ordo serangga yang berperan sebagai predator lebih banyak dibandingkan parasitoid. Serangga parasitoid hanya terbatas pada ordo Hymenoptera, Diptera dan Strepsiptera. (Armando, 2016) menemukan pada lahan kelapa sawit menghasikan, serangga predator lebih banyak dibandingkan serangga parasitoid dengan persentase $78.50 \%$ predator dan $1.48 \%$ parasitoid. Hal yang sama juga dilaporkan (Pelawi, 2009) bahwa pada lahan kelapa sawit belum menghasilkan, kelimpahan serangga predator lebih banyak dibandingkan kelimpahan serangga parasitoid dengan jumlah sebanyak 66 individu serangga predator dan 35 individu serangga parasitoid.

Faktor lain yang menyebabkan kelimpahan serangga predator lebih tinggi dibandingkan dengan serangga parasitoid adalah ketersedian mangsa dan inang. Serangga herbivor yang merupakan mangsa bagi serangga predator lebih banyak tersedia di dalam ekosistem dibandingkan serangga inang bagi serangga parasitoid. Hal ini berhubungan dengan sifat serangga predator dan parasitoid itu sendiri. Sebagian besar serangga predator bersifat generalis yaitu memiliki kisaran mangsa yang luas, sedangkan serangga parasitoid bersifat spesifik yaitu hanya menyerang spesies tertentu sebagai inang (Snyder \& Ives, 2003).

Serangga predator yang memiliki kelimpahan individu tertinggi pada semua lahan yakni Formicidae (Hymenoptera) (Gambar 2a). Jumlah individu famili Formicidae pada lahan kakao-kelapa sawit yakni 632 individu. Jumlah individu famili Formicidae pada lahan kakao, lahan kelapa sawit dan lahan hutan berturut-turut yakni 791, 302, dan 250 individu (Tabel 2). (Azhar, 2015) menyatakan bahwa famili Formicidae lebih dominan dibandingkan famili serangga predator lainnya dengan jumlah individu yakni 3,165 individu dari 3,293 individu total serangga predator yang ditemukan pada perkebunan kelapa sawit berbagai tingkatan umur di Kabupaten Sarolangun, Jambi. (Anbalagan, Paulraj, Ignacimuthu, Baskar, \& Gunasekaran, 2016) pada penelitiannya mengungkapkan hal yang sama bahwa Formicidae merupakan famili serangga predator dengan kelimpahan individu tertinggi. Formicidae atau semut merupakan kelompok yang umum dan menyebar luas karena memiliki habitat di manamana dan jumlah individunya melebihi kebanyakan hewan darat lainnya (Borror, Triplehorn, \& Johnson, 1996). Beberapa spesies semut memiliki potensi yang tinggi untuk beradaptasi pada berbagai kondisi lingkungan, sehingga mudah ditemukan di berbagai habitat di seluruh dunia (Patkar \& Chavan, 2014).

Serangga parasitoid yang memiliki kelimpahan individu tertinggi pada setiap lahan berbeda, namun sebagian besar berasal dari ordo Hymenoptera. (Quicke, 1997) menyatakan bahwa sekitar 80\% serangga parasitoid berasal dari ordo Hymenoptera. Selain dari ordo Hymenoptera, serangga parasitoid juga berasal dari ordo Diptera. Famili dengan kelimpahan individu tertinggi yakni Braconidae pada lahan kakao-kelapa sawit (Gambar 2b), Tachinidae pada lahan kakao (Gambar 2c), Tiphiidae pada lahan kelapa sawit (Gambar 2d) dan Ichneumonidae pada hutan (Gambar 2e).

Dilihat dari total keseluruhan serangga parasitoid yang ditemukan, famili dengan kelimpahan tertinggi adalah famili Braconidae dan Ichneumonidae dengan kelimpahan individu yang sama yakni 47 individu (Tabel 2). Famili Braconidae dan Ichneumonidae berada dalam super famili yang sama yakni Ichneumonoidea. Famili Braconidae merupakan famili yang dapat hidup pada berbagai kondisi iklim dan habitat, sehingga anggota famili ini dapat ditemukan di mana saja (Sharkey \& Wahl, 1992). Famili Braconidae diketahui dapat memarasit larva dari ordo Coleoptera, Diptera, dan Lepidoptera, sedangkan famili Ichneumonidae biasanya 
memarasiti larva atau pupa dari Coleoptera dan Indeks keanekaragaman pada lahan kakao-kelapa
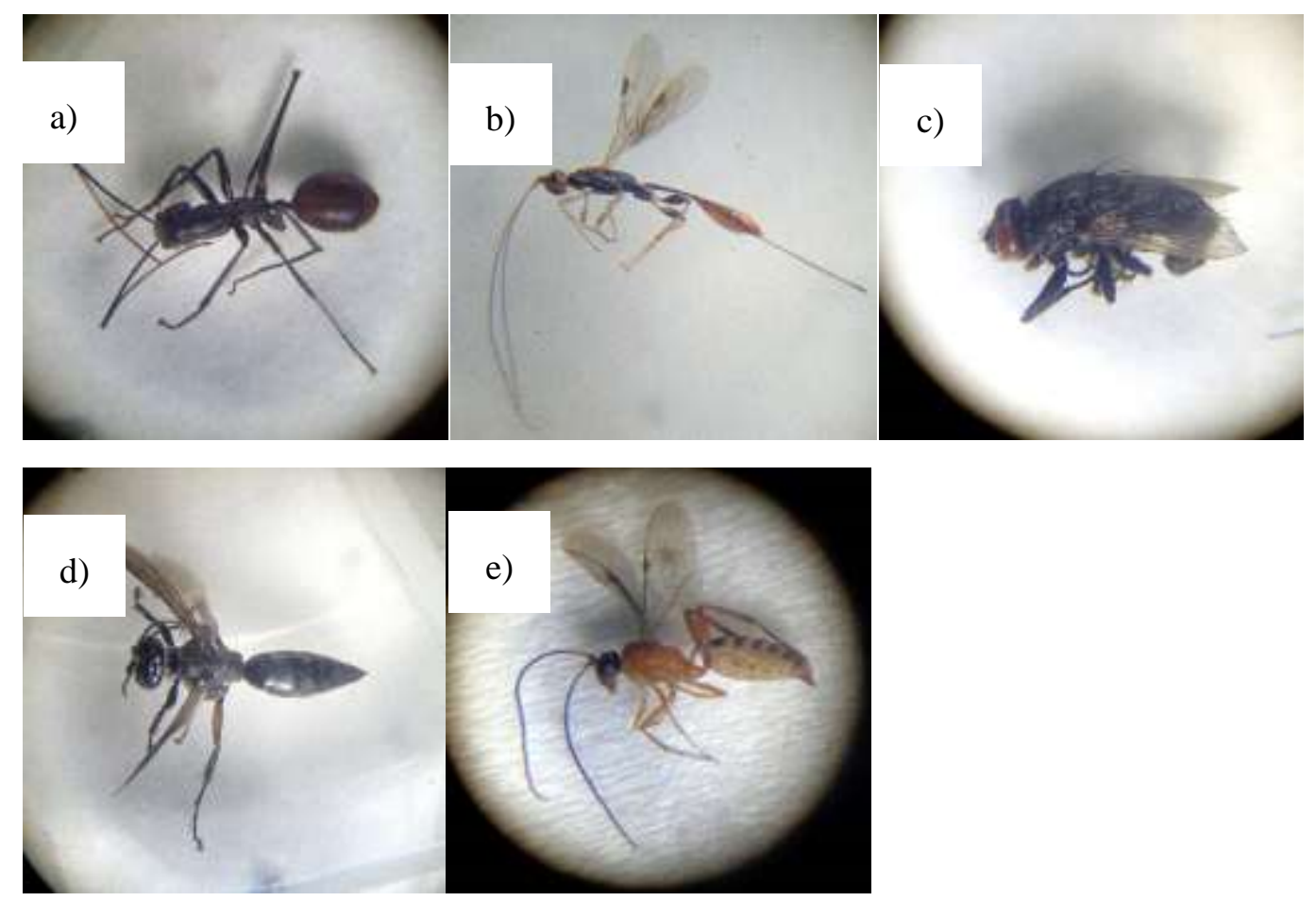

Gambar 2. Serangga dengan kelimpahan tertinggi:a)Formicidae,b)Braconidae, c)Tachinidae,d)Tiphiidae, e)Ichneumonidae

Lepidoptera (Goulet \& Huber, 1993).

\section{Pengaruh Tipe Penggunaan Lahan}

Kekayaan spesies dipengaruhi oleh tipe penggunaan lahan $(p=0.0005)$. Indek kekayaan spesies pada lahan kakao-kelapa sawit dan kakao adalah 29.00 dan 21.50 sedangkan nilai kekayaan spesies pada lahan kelapa sawit dan hutan berturut-turut yakni 24.00 dan 31.00 (Tabel 3). Kekayaan spesies pada lahan kakao-kelapa sawit lebih tinggi dan berbeda nyata dibandingkan dengan kekayaan spesies pada lahan kakao, lahan kelapa sawit dan lahan hutan. Kelimpahan individu dipengaruhi oleh tipe penggunaan lahan ( $p=0.0155)$. Kelimpahan individu pada lahan kakao-kelapa sawit tidak berbeda nyata dibandingkan dengan kelimpahan individu pada lahan kakao, sedangkan bila dibandingkan dengan kelimpahan individu pada lahan hutan dan kelapa sawit adalah berbeda nyata. sawit, kelapa sawit dan hutan tergolong ke dalam nilai sedang $\left(H^{\prime}=1-3\right)$, sedangkan Indeks keanekaragaman pada lahan kakao tergolong rendah $\left(H^{\prime}<1\right)$. Keanekaragaman serangga predator dan parasitoid dipengaruhi oleh tipe penggunaan lahan $(p=0.0034)$. Keanekaragaman serangga predator dan parasitoid pada lahan kakao-kelapa sawit lebih tinggi dan berbeda nyata dibandingkan pada lahan kakao. Hal ini disebabkan oleh berbagai faktor yakni kegiatan budidaya, vegetasi, ketersediaan pakan/mangsa dan inang serta faktor biologis serangga predator dan parasitoid.

Faktor-faktor tersebut saling terhubung satu sama lain. Pertama dilihat dari kegiatan budidaya pada lahan kakao lebih intensif dibandingkan lahan kakao kelapa sawit. Lahan dengan intensitas kegiatan budidaya yang rendah memiliki kekayaan spesies serangga predator yang tinggi (Philpott, Arendt, \& Armbrecht, 2008) 
Tabel 2. Kelimpahan serangga predator dan parasitoid pada lahan kakao- kelapa sawit, kakao, kelapa sawit, dan hutan

\begin{tabular}{|c|c|c|c|c|c|c|}
\hline \multirow{2}{*}{ Ordo } & \multirow{2}{*}{ Famili } & \multicolumn{4}{|c|}{ Jumlah Individu } & \multirow[t]{2}{*}{ Peranan } \\
\hline & & $* \mathbf{K k}$ & Ko & Ks & Ht & \\
\hline \multirow{3}{*}{ Coleoptera } & Carabidae & 5 & 4 & 6 & 12 & Predator \\
\hline & Cicindelidae & 7 & 2 & 1 & 13 & Predator \\
\hline & Cleridae & 0 & 0 & 1 & 9 & Predator \\
\hline \multirow{3}{*}{ Dermaptera } & Coccinellidae & 6 & 13 & 5 & 4 & Predator \\
\hline & Forficulidae & 4 & 0 & 4 & 4 & Predator \\
\hline & Asilidae & 7 & 7 & 2 & 9 & Predator \\
\hline \multirow{6}{*}{ Diptera } & Conopidae & 6 & 0 & 3 & 5 & Parasitoid \\
\hline & Dolichopodidae & 10 & 4 & 47 & 8 & Predator \\
\hline & Muscidae & 8 & 2 & 0 & 15 & Predator \\
\hline & Sciaridae & 20 & 4 & 2 & 8 & Predator \\
\hline & Tachinidae & 7 & 15 & 4 & 6 & Parasitoid \\
\hline & Tipulidae & 11 & 8 & 0 & 5 & Predator \\
\hline \multirow{4}{*}{ Hemiptera } & Anthocoridae & 6 & 0 & 4 & 7 & Predator \\
\hline & Lygaeidae & 5 & 0 & 2 & 3 & Predator \\
\hline & Nabidae & 6 & 8 & 0 & 9 & Predator \\
\hline & Pentatomidae & 7 & 12 & 3 & 5 & Predator \\
\hline \multirow{11}{*}{ Hymenoptera } & Reduviidae & 5 & 10 & 3 & 9 & Predator \\
\hline & Bethylidae & 0 & 0 & 0 & 6 & Parasitoid \\
\hline & Braconidae & 11 & 10 & 5 & 21 & Parasitoid \\
\hline & Eulophidae & 0 & 0 & 0 & 9 & Parasitoid \\
\hline & Evanidae & 6 & 6 & 4 & 7 & Parasitoid \\
\hline & Formicidae & 632 & 791 & 302 & 250 & Predator \\
\hline & Ichneumonidae & 10 & 6 & 8 & 23 & Parasitoid \\
\hline & Pemphredonidae & 7 & 5 & 4 & 15 & Parasitoid \\
\hline & Scelionidae & 0 & 0 & 0 & 11 & Parasitoid \\
\hline & Sphecidae & 4 & 1 & 3 & 6 & Predator \\
\hline & Tiphiidae & 6 & 3 & 11 & 11 & Parasitoid \\
\hline & Vespidae & 4 & 5 & 3 & 8 & Predator \\
\hline Mantodea & Mantidae & 3 & 2 & 0 & 0 & Predator \\
\hline \multirow[t]{2}{*}{ Odonata } & Coenagrionidae & 17 & 3 & 14 & 6 & Predator \\
\hline & Libellulidae & 5 & 0 & 3 & 9 & Predator \\
\hline Orthoptera & Gryllidae & 39 & 13 & 8 & 66 & Predator \\
\hline Thysanoptera & Phlaeothripidae & 14 & 0 & 3 & 0 & Predator \\
\hline
\end{tabular}

* Kk: kakao-kelapa sawit, Ko: kakao, Ks: kelapa sawit, Ht: Hutan

Lahan dengan intensitas kegiatan budidaya yang rendah akan memiliki banyak vegetasi dibandingkan lahan dengan intensitas kegiatan budidaya yang tinggi. Vegetasi yang banyak pada lahan kakaokelapa sawit akan mengundang kedatangan serangga herbivor yang banyak pula. Banyaknya serangga herbivor pada suatu lahan berarti banyaknya ketersediaan mangsa dan inang bagi serangga predator dan parasitoid. Serangga predator dan parasitoid yang membutuhkan mangsa dan inang untuk meneruskan stadia hidupnya akan datang mencari mangsa dan inang ke lahan tersebut. Vegetasi yang berbunga juga mengundang serangga parasitoid datang karena nektar yang dihasilkan merupakan pakan bagi serangga parasitoid dewasa.

Dilihat dari hasil uji lanjut Tukey dapat dinyatakan bahwa ketika lahan kakao monokultur diubah menjadi polikultur yaitu mengintegrasikannya dengan kelapa sawit, maka akan mempengaruhi keanekaragaman serangga predator dan parasitoid di dalamnya. 
Tabel 3. Pengaruh tipe penggunaan lahan kakao-kelapa sawit terhadap kekayaan jenis (S), kelimpahan individu (N), Indeks keanekaragaman Shannon-Wiener (H') dan indeks kemerataan Simpson (E)

\begin{tabular}{lllll}
\hline \multirow{2}{*}{ Tipe Penggunaan Lahan } & \multicolumn{4}{c}{ Lahan } \\
\cline { 2 - 5 } & $\mathbf{S}$ & $\mathbf{N}$ & $\mathbf{H}$ & $\mathbf{E}$ \\
\hline Kakao-Kelapa sawit & $29.00 \mathrm{~b}$ & $439.00 \mathrm{ab}$ & $1,46 \mathrm{~b}$ & $0,48 \mathrm{~b}$ \\
Kakao & $21.50 \mathrm{~d}$ & $467.00 \mathrm{a}$ & $0,86 \mathrm{c}$ & $0,28 \mathrm{c}$ \\
Kelapa sawit & $24.50 \mathrm{c}$ & $227.50 \mathrm{c}$ & $1,53 \mathrm{~b}$ & $0,55 \mathrm{~b}$ \\
Hutan & $31.00 \mathrm{a}$ & $289.50 \mathrm{bc}$ & $2,44 \mathrm{a}$ & $0,79 \mathrm{a}$ \\
\hline
\end{tabular}

Keterangan: angka yang diikuti huruf yang sama pada satu kolom menunjukkan nilai yang tidak berbeda nyata berdasarkan uji Tukey dengan taraf nyata 5\%.

Pengaruh ini bersifat positif yaitu terjadinya peningkatan keanekaragaman serangga predator dan parasitoid. Berbeda jika lahan kelapa sawit monokultur yang diubah menjadi lahan polikultur dengan mengintegrasikannya dengan kakao ataupun komoditi lainnya, dimana tidak adanya pengaruh terhadap keanekaragaman serangga predator dan parasitoid di dalamnya. Hal yang sama dilaporkan (Arifin, Mokhamad, Indah, Aulia, \& Ahmad, 2016) bahwa tidak adanya perbedaan yang nyata keanekaragaman serangga pada lahan kelapa sawit yang ditumpangsarikan dengan tanaman jagung (polikultur) dibandingkan pada lahan kelapa sawit monokultur (2.84;2.37). Faktor lain yang menyebabkan tidak adanya perbedaan keanekaragaman serangga predator dan parasitoid pada lahan kakao-kelapa sawit dan lahan kelapa sawit adalah ketentuan dalam menentukan indeks keanekaragaman yang tidak hanya memperhatikan kekayaan spesies saja, tetapi juga memperhatikan kemerataan spesies. Nilai keanekaragaman adalah resultante dari nilai kekayaan dan kemerataan spesies (Hamid \& Yunisman, 2007).

Diketahui bahwa kekayaan spesies pada lahan kakaokelapa sawit lebih tinggi dibandingkan lahan kelapa sawit, namun karena adanya salah satu famili serangga yang mendominasi dengan jumlah individu yang jauh sangat tinggi dibandingkan dengan jumlah individu pada famili lainnya menyebabkan nilai indeks keanekaragaman lahan kakao-kelapa sawit dan lahan kelapa sawit sama. Hal ini juga dapat dilihat dari indeks kemerataan, yang mana indeks kemerataan pada lahan kakao-kelapa sawit tidak berbeda nyata dibandingkan dengan lahan kelapa sawit.

Keanekaragaman serangga predator dan parasitoid pada lahan hutan lebih tinggi dan berbeda nyata dibandingkan dengan keanekaragaman serangga predator dan parasitoid pada lahan kakao-kelapa sawit. Begitupun indeks kemerataan serangga predator dan parasitoid pada lahan hutan lebih tinggi dan berbeda nyata dibandingkan dengan keanekaragaman serangga predator dan parasitoid pada lahan kakao-kelapa sawit. Hal ini dikarenakan lahan hutan merupakan source atau sumber kekayaan genetik. (Indriyanto, 2012) menyatakan bahwa hutan merupakan ekosistem yang komplek, dimana hutan berperan sebagai gudang plasma nutfah (sumber genetik) dari berbagai jenis tumbuhan (flora) dan hewan (fauna).

\section{Persebaran Serangga Predator dan Parasitoid pada Lahan Kakao yang Diintegrasikan dengan Kelapa Sawit}

Pada penelitian ini terdapat dua lahan kakao yang diintegrasikan dengan kelapa sawit. Total serangga predator dan parasitoid yang ditemukan pada kedua lahan yakni 9 ordo yang terdiri dari 29 famili, 49 morfospesies dan 878 individu. Famili serangga predator dan parasitoid yang terdapat pada kedua lahan adalah sama. Hal ini dikarenakan tanaman pokok pada kedua lahan yang sama dan letak yang 
berdekatan. Jika suatu lahan terletak berdekatan dengan lahan lainnya maka akan mempengaruhi komposisi serangga pada kedua lahan tersebut, walaupun tipe penggunaannya berbeda. Hal ini menunjukan bahwa adanya pengaruh positif dari letak lahan yang berdekatan terhadap persebaran serangga. (Rizali, Buchori, \& Triwidodo, 2002) mengungkapkan bahwa lahan sawah yang berdekatan dengan hutan memiliki nilai kesamaan komposisi spesies yang tinggi.

Persebaran serangga tidak hanya terjadi di antara beberapa lahan, tetapi juga terjadi dalam areal suatu lahan tersebut. Persebaran serangga dalam suatu lahan dapat dipengaruhi oleh berbagai faktor, diantaranya ketersediaan tempat tinggal dan makanan/pakan. Selain itu, persebaran serangga juga dipengaruhi oleh pola persebaran populasi serangga. Menurut (Ludwig \& Reynolds, 1988), terdapat tiga pola dasar persebaran populasi dalam suatu habitat, parasitoid pada lahan kakao-kelapa sawit II pada setiap petak sampelnya berbeda. Pada petak sampel 1 dan petak sampel 2 ditemukan 16 famili dan 14 famili, sedangkan pada petak sampel 3, petak sampel 4, dan petak sampel 5 masing-masing ditemukan 14, 19, dan 16 famili (Gambar 3b).

\section{KESIMPULAN}

Indeks keanekaragaman pada lahan kakao-kelapa sawit, kakao, kelapa sawit dan hutan berturut-turut yakni 1.459, $0.875,1.534$ dan 2.437. Jenis penggunan lahan berpengaruh terhadap keanekaragaman serangga predator dan parasitoid. Lahan kakao yang diintegrasikan dengan kelapa sawit memberikan pengaruh yang besar terhadap keanekaragaman serangga predator dan parasitoid.

\section{Daftar Pustaka}

Anbalagan, V., Paulraj, M. G., Ignacimuthu, S., Baskar,

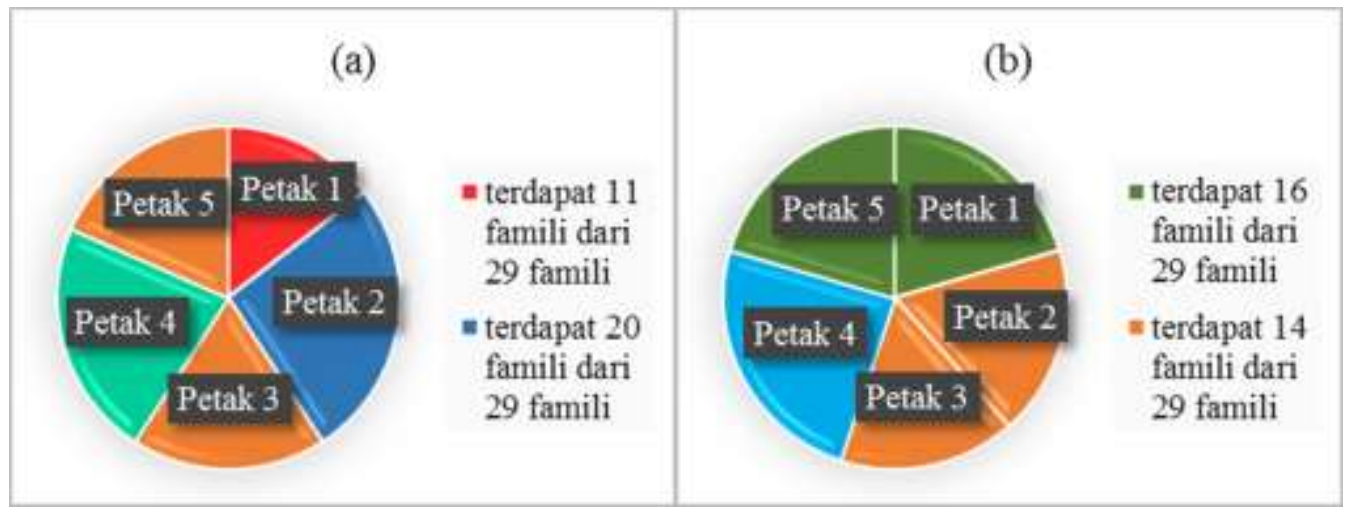

Gambar 3. Diagram Persebaran serangga pada setiap petak sampel pada lahan a)kakao-kelapa sawit I, b)kakao-kelapa sawit II

yaitu pola acak, mengelompok dan seragam.

Pada lahan kakao-kelapa sawit I dan II terdapat masing-masing 5 petak sampel. Famili serangga predator dan parasitoid yang ditemukan pada lahan kakao-kelapa sawit I dan II yakni 29 famili. Persebaran serangga predator dan parasitoid pada lahan kakao-kelapa sawit I pada setiap petak sampelnya berbeda. Pada petak sampel 1 ditemukan 11 famili, sedangkan pada petak sampel 2, petak sampel 3, petak sampel 4, dan petak sampel 5 masing-masing ditemukan 20, 14, 17, dan 14 famili (Gambar 3a). Persebaran serangga predator dan
K., \& Gunasekaran, J. (2016). Natural enemy (Arthropoda-Insecta) biodiversity in vegetable crops in Northeastern Tamil Nadu, India. (Vol. 53). International Letters of Natural Sciences.

Arifin, L., Mokhamad, I., Indah, P., Aulia, R. A., \& Ahmad, T. A. (2016). Keanekaragaman serangga pada tumpangsari tanaman pangan sebagai tanaman sela di pertanaman kelapa sawit belum menghasilkan. $J$. Agroteknologi, 7 (1), 33-40.

Armando, R. (2016). Pengaruh Kondisi Habitat Kelapa Sawit (Elaeis guineensis Jacq.) terhadap Arthropoda dan Hama Tikus. Tesis, Institut Pertanian Bogor, Sekolah Pascasarjana, Bogor.

Azhar, A. (2015). Keanekaragaman serangga predator pada berbagai tingkatan umur kelapa sawit (Elaeis 
guineensis Jacq.) di Kabupaten Sarolangun, Jambi. Skripsi, Institut Pertanian Bogor, Bogor.

Borror, D. J., Triplehorn, C. A., \& Johnson, N. F. (1996). Pengenalan Pelajaran Serangga Edisi ke-6. Partosoedjono S, penerjemah. (T. d. Insects, Penerj.) Yogyakarta: Gadjah Mada University Press.

BPS. (2017). Dharmasraya dalam angka. Dharmasraya: Badan Pusat Statistik.

Dinas Pertanian. (2017). Data statistik komoditi perkebunan di Kabupaten Dharmasraya. Dharmasraya: Dinas Pertanian Dharmasraya.

Goulet, H., \& Huber, J. T. (1993). Hymenoptera of the World: An Identification Guide to Families. Ottawa: Canada Communications Group.

Hamid, H., \& Yunisman. (2007). Keanekaragaman Hymenoptera parasitoid pada berbagai ekosistem pertanian di Sumatera Barat. Laporan Penelitian, Universitas Andalas, Jurusan Hama dan Penyakit Tumbuhan, Fakultas Pertanian, Padang.

Indriyanto. (2012). Ekologi Hutan. Jakarta: PT Bumi Aksara.

Krebs. (1978). Ecology. The Experimental Analysis of Distribution and Abudance Third Edition. Dalam Rosalyn, I. Indeks keanekaragaman serangga pada pertanaman kelapa sawit (Elaeis guineensis Jacq.) di kebun Tanah Raja Perbaungan PT. Perkebunan Nusantara III. skripsi, Universitas Sumatera Utara, Medan.

Ludwig, J. A., \& Reynolds, J. F. (1988). Statistical Ecology: A primer method and computing. New York. Dalam Basna, M., Koneri R., Papu A. Distribusi dan diversitas serangga tanah di Taman Hutan Raya Gunung Tumpa Sulawesi Utara. Jurnal MIPA UNSRAT, 6 (1), 36-42.

Patkar, N. B., \& Chavan, R. J. (2014). Diversity of ants (Hymenoptera: Formicidae) from undisturbed and disturbed habitats of great Indian bustard wildlife sanctuary. (M.S.). International Journal of Scientific Research, 3(12), 398-401.

Pelawi, A. (2009). Indeks keanakaragaman jenis serangga pada beberapa ekosistem di areal perkebunan PT. Umbulmas Wisesa Kabupaten Labuhan Batu. Skripsi, Universitas Sumatera Utara, Medan.

Philpott, S. M., Arendt, W. J., \& Armbrecht, I. (2008). Biodiversity loss in Latin American coffee landscapes: Review of the evidence on ants, birds, and trees. Waltham: Academic Press.

Quicke, D. L. (1997). Parasitic Wasp. London: Chapman and Hall.

Rizali, A., Buchori, D., \& Triwidodo, H. (2002). Keanekaragaman serangga pada lahan persawahantepian hutan: indikator untuk kesehatan lingkungan (Vol. 9(2)).
Sharkey, M. J., \& Wahl, D. B. (1992). Cladistic of the Ichneumonoidea (Hymenoptera). Jurnal Hym, 1, 1524.

Snyder, W. E., \& Ives, A. R. (2003). Interactions between specialist and generalist natural enemies: parasitoids, predators, and pea aphid biocontrol. Ecology, 84(1), 91-107. 